\title{
Improving the Resilience of Central Asian Agriculture to Weather Variability and Climate Change
}

\author{
Alisher Mirzabaev
}

\begin{abstract}
Central Asia is projected to experience significant climate change, combined with increased weather volatility. Agriculture is a key economic sector and a major source of livelihoods for Central Asia's predominantly rural population, especially for the poor. Agricultural production, being sensitive to weather shocks and climate volatility, may be negatively affected by climate change if no adaptive actions are taken. Climate smart technologies could help in strengthening the resilience of agricultural producers in the region to increased weather variability due to climate change. This study identifies the key barriers and opportunities for a wider adoption of climate smart technologies and also evaluates their potential impacts on agricultural revenues of differentiated groups of agricultural producers, with a focus on the poor. Adoption of climate smart agricultural technologies was found to raise farming profits of both poorer and richer households, although these positive impacts may likely to be higher for richer households. The study also shows that policies facilitating improved access to markets and agricultural extension services, as well as higher commercialization of household agricultural output may increase the adoption of climate smart agricultural technologies in the region.
\end{abstract}

\section{Introduction}

The four countries of Central Asia - Kazakhstan, Kyrgyzstan, Tajikistan and Uzbekistan - are located in arid, semiarid and sub-humid regions. The climate in the region is intrinsically volatile, with often recurring weather shocks, such as droughts, heatwaves, frosts and hails (Gupta et al. 2009). Agriculture is an important sector for the region. Even in richer Kazakhstan, where the share of agriculture is $6 \%$ of the Gross Domestic Product (GDP), it employs almost $30 \%$ of the labor force. In the rest of the region, the share of agriculture in GDP is as high as 30\% in Kyrgyzstan, and in employment as high as 66\% in Tajikistan (Mirzabaev 2013). Thus,

\footnotetext{
A. Mirzabaev $(\triangle)$

University of Bonn, Bonn, Germany

e-mail: almir@uni-bonn.de
} 
agriculture is a major source of livelihood, especially for the rural poor. Because agricultural production is sensitive to weather, increased weather variability due to climate change may have a negative impact on agricultural production and farming incomes. Therefore, appropriate actions are needed to dynamically adapt the agricultural practices to changing climatic and weather conditions (Zilberman et al. 2012). In this context, the poorest rural households are more vulnerable to climate change because they have lower adaptive capacities and higher dependence on farming incomes. In fact, Mirzabaev (2013) finds that every 10\% decrease in farming incomes due to weather variability in the region is likely to reduce the per capita food consumption of the poorest quartile of households by $5.2 \%$, while a similar decrease in farming incomes would result only in $3.9 \%$ decrease in the per capita food expenses of the richest 10\% of rural households. Taking this into account, any analysis of adaptation to climate change would be deficient unless it specifically looks into the factors that enable or prevent the poorest agricultural households from adapting to increased weather variability and climate change. Ultimately, major impacts of climate change are expected to be not through aggregate changes, but through their distributional effects (Zilberman et al. 2004).

Despite a decade of strong economic growth, rural incomes remain low in many parts of the region, with related challenges of food insecurity and rural poverty. Adaptive actions are required not only to cope with weather shocks, but also for being resilient enough to successfully overcome the negative impacts of weather shocks and achieve agricultural growth and rural poverty reduction. The adoption of sustainable and climate-smart agricultural technologies (CSATs) could help in increasing such a resilience of agricultural households to climate change (Lipper et al. 2014). This is especially important in the context of significant uncertainties about the direction and magnitudes of climate change impacts in Central Asia. Limited resources require that these adaptive actions are made up of no-regret measures, capable of positively contributing to regional food security, agricultural growth and poverty reduction even with perfect climate change mitigation.

Based on the above problem compounded by regional challenges, the proposed study seeks to answer the following research questions:

1. what are the key barriers and catalysts for the adoption of CSATs in Central Asia, and

2. what may be the distributional effects of the adoption of CSATs on the farming revenues of different categories of agricultural households, with a focus on the poor?

\section{Literature Review}

\subsection{Climate Change in Central Asia}

The regional downscaling of IPCC forecasts for Central Asia (de Pauw 2012) indicates that there may be likely increases in the average annual mean, minimum and maximum temperatures throughout the region, though the 
temperature increases would be lower in the west of the region near the Caspian Sea, and higher in the north of the region (de Pauw 2012). In general, the annual precipitation may increase in the region, with higher increases in the north of the region, and some slight decreases in the south of the region. Spring and fall precipitations are likely to increase while summer precipitation to decrease. Wetter winters may be more frequent, as well as drier springs, summers and autumns. However, unlike the temperature projections there are big disagreements among different models on the direction and magnitudes of precipitation changes in the region. Warming could increase the water run-off in Central Asia for decades, or even centuries as suggested by Gupta et al. (2009). However, the seasonality of runoff may change, with more runoff in spring and less in summer (ibid). Moreover, Stulina (2008) indicates that forecasts of the flow of the Amudarya and Syrdarya Rivers strongly vary depending on the model. For example, under the Geophysical Fluid Dynamics Laboratory (GFDL) model of the United States' National Oceanic and Atmospheric Administration (NOAA), there may be $1 \%$ increase in the average flow of Syrdarya and no change in the flow of Amudarya by 2030. In contrast, using the Canada Climate Change Model (CCCM) may lead to predictions of significant decreases in the flow of both rivers, $-28 \%$ and $-40 \%$ for Syrdarya and Amudarya, respectively (ibid.). All in all, the climate change forecasts for Central Asia indicate that temperatures may be rising all across the region. There is no consensus in precipitation and water run-off predictions.

Mirzabaev (2013) estimates the aggregate impacts of climate change on Central Asian agriculture to range between $+1.21 \%$ and $-1.43 \%$ of net crop production revenues by 2040 . Though small in relative terms, the absolute monetary impact is not negligible, ranging from $+180 \mathrm{mln}$ USD annually in the optimistic scenario, to -210 mln USD annually in the pessimistic scenario relative to 2010 levels, where optimistic and pessimistic scenarios are defined to correspond to B1 (lowest future emission trajectory) and A1FI (highest future emission trajectory) scenarios by IPCC (2007), respectively. However, these aggregate impacts have significant geographic and socio-economic distributional effects, whereby the poorer provinces in Central Asia and poorest agricultural households would be affected more negatively by climate change due to their lower adaptive capacities and higher dependence on agricultural incomes (Mirzabaev 2013). This is also supported by several other studies on the region. Nelson et al. (2010) find that by 2050, climate change may lead to higher rainfed wheat yields in Kazakhstan and Kyrgyzstan (by 0-11\%), while in Tajikistan, Turkmenistan and Uzbekistan rainfed wheat yields may decline (by 8-18\%). The yields for irrigated wheat may decrease in all countries (by 7-14\%), except in Uzbekistan (+1\%). Sommer et al. (2013) find that wheat yields may grow on average by $+12 \%$ across Central Asia, ranging from $-3 \%$ to $+27 \%$. Bobojonov et al. (2012) estimate that during 2040-2070, the climate change may increase agricultural incomes in northern rainfed areas of Central Asia (in some areas by up $50 \%$ ), and reduce incomes in the southern irrigated areas, especially under the conditions of water scarcity (in some areas by more than 17\%). 
As we can see from these studies, major impacts of climate change in Central Asia are likely to be through their negative effects on the poorest agricultural households, while the aggregate effects do not seem to be substantial relative to the overall economy. Therefore, the link between climate change and poverty is vital for responses to climate change in the region. In this regard, climate smart agriculture may help reduce vulnerability by stabilizing or even increasing agricultural production (Meinzen-Dick et al. 2012; Wheeler and von Braun 2013).

\subsection{The Role of Climate-Smart Agricultural Technologies}

Climate smart agriculture is an approach to transform agricultural systems and to support food security under a changing climate by providing context-specific and flexible solutions (Lipper et al. 2014). In general, climate-smart agriculture has three objectives (McCarthy and Brubaker 2014):

1. Increasing agricultural productivity in a sustainable way, and to support equitable increases in farm income, food security and development

2. Strengthening the resilience of agricultural and food security systems towards climate change

3. Reducing greenhouse gas emissions from agriculture (including crops, livestock and fisheries).

Thus, climate-smart agriculture has, in fact, wide-reaching implications beyond narrowly defined climate change and adaptation to it, and covers a broad spectrum of sustainable development objectives. Climate-smart agriculture involves technological, institutional and policy solutions. For example, a crop rotation with nitrogen-fixing crops increases biomass production. Diverse production systems tend to produce more biomass than monocultures (Tilman et al. 2006), which also entails opportunities of additional carbon storage. Improved water management also has impacts on biomass production as it can increase the amount of water in the root zone and therefore enhances carbon sequestration potential (Kimmelshue et al. 1995). Reduced tillage could lead to decreases in carbon losses (Branca et al. 2011). Gupta et al. (2009) indicate several dozen of such climate smart technologies experimented with in Central Asia for the last decade, such as zero tillage, direct seeding, cutback and zigzag irrigation, double cropping, etc. The corresponding economic analyses of these technologies also show that many of them have positive cost-benefit ratios (Pender et al. 2009), i.e. could be used as no-regret options for both adapting to climate change, sustainably managing soil and water resources, and raising farming productivity and incomes. 


\section{Conceptual Framework}

The adoption of CSATs, like those listed above, could be highly useful to strengthen the resilience of the agricultural households and improve their capacities to adapt to climate change. In general, adaptation can be considered as all changes an individual or an institution, such as government, makes to adjust to a changing environment (Osberghaus et al. 2010; Seo 2011). However, when faced with slow onset uncertain risks such as climate change, raising public awareness could be necessary for correct attribution of the causes of on-going climatic changes and appropriate reactions to these changes. It also needs to be acknowledged, as suggested by Nhemachena and Hassan (2007) and Mertz et al. (2009), that adaptation measures undertaken by farmers may have other driving forces than actual climate effects. For this reason, adaptation actions are a function of both perceiving the risks associated with the climate change, but are also dependent on personal environmental knowledge and beliefs, as well as personal characteristics such as gender, age, education, etc. (O'Connor et al. 1999).

Adaptation can be classified into two categories: (i) private adaptation and (ii) public adaptation (Mendelsohn 2000). Private adaptation is undertaken by individuals themselves seeking to maximize their utility, while public adaptation is undertaken by governments seeking to achieve a higher public benefit for the entire society (Osberghaus et al. 2010). Adaptation can happen ex post or ex ante to a climatic shock (Mendelsohn 2000).

The vulnerability of agricultural production to climatic and weather changes is greatly modulated by timely adaptation and coping actions. However, when evaluating uncertain and low probability events individuals may often make decisions based on their intuitive risk judgments, i.e. perceptions, rather than rational expected utility maximization (Tversky and Kahneman 1986), which is influenced by individual's previous experiences, education, age, gender, socio-economic, institutional, cultural and other characteristics. However, perceiving climate change is not by itself sufficient for adapting to it. One of the key incentives for successful adaptation is when agricultural producers do perceive that climate is changing and that this change is affecting their agricultural activities, necessitating them to take appropriate actions to modify their farming practices to better suit the new climate. Households start adapting only when the costs of inaction on the changes that they perceive outweigh the costs of adaptive actions. Even if households perceive certain changes in the climate, they may still be unwilling to incur costs of adapting to these changes if these changes do not pose a sufficiently high level of damage risk, especially since individuals tend to underestimate the occurrence of low probability events (Tversky and Kahneman 1986).

Even when households perceive the changes and are willing to take adaptive actions, they may still be constrained by low adaptive capacities. Households' adaptive capacities, in turn, depend on their resource endowments, specifically, their access to five "capitals": human, natural, financial, social and physical (Chambers and Conway 1992), which largely fashion households' resilience to external shocks, including weather and climate shocks. A major purpose of the analysis would be to 


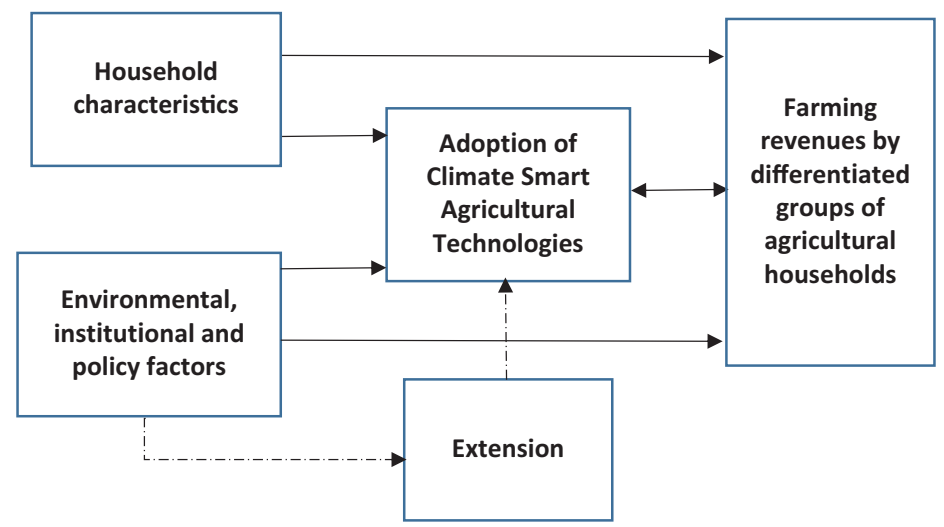

Fig. 1 The conceptual framework of causal relationships

estimate the impact of the adoption of CSATs by different categories of surveyed households, with a focus on the poorer households.

Following these broad outlines, this study is based on the conceptual framework of causal links shown below (Fig. 1), which also motivated the empirical strategy outlined in the following section.

The conceptual framework indicates that both the adoption of climate smart technologies and farming incomes depend on the characteristics of agricultural households and the environmental, institutional and policy factors affecting the decision making by households. The adoption of CSATs would also affect the farming incomes. However, the relationship is likely to be endogenous, whereby farming incomes of the households would also influence their decisions about the adoption of CSATs. To address this endogeneity, access to agricultural extension services would be used as an instrumental variable. Extension services on CSATs are provided for free to agricultural households in the region (also corroborated by the survey dataset used in this study) by government-run farming associations or nonprofit organizations, and therefore, is likely to influence farming incomes only through its impact on the adoption of CSATs, and is not influenced by farming incomes of the households.

\section{Empirical Framework}

\subsection{Data}

The dataset used for this analysis comes from nationally representative agricultural household surveys conducted in the four countries of Central Asia studied in this paper. The survey covers the 2009-2010 cropping season. The multi-stage survey 
sampling was conducted in a way to ensure representativeness of the survey sample with the overall population of agricultural producers: farmers and household producers, across different agro-ecologies and farming systems in each country. The confidence interval of $95 \%$ was used to calculate the sample size. The calculated sample size varied between 380 and 385 respondents between the countries. To compensate for any missing or failed cases, the actual sample size for each country was determined to be 400 respondents, i.e. 1600 respondents in total.

Uzbekistan and Kazakhstan (the larger countries in the dataset) were first divided into major agro-ecological zones - west, south, center and east for Uzbekistan, north, center, west, south and east for Kazakhstan. Then in each zone, one province was randomly selected. In the case of Tajikistan and Kyrgyzstan (the smaller countries) all provinces were selected for further sampling of villages in each of them. The number of respondents was allocated to each province depending on the share of the agro-ecological zone (or province, in the cases of Tajikistan and Kyrgyzstan) in the value of the national agricultural production.

Following this, the total list of villages was obtained for each province selected. The villages in each province were numbered, and the corresponding numbers for the selected villages were randomly drawn (35 villages in Kazakhstan, 22 in Kyrgyzstan, 25 in Tajikistan, 25 in Uzbekistan). The number of respondents per village was evenly distributed within each province. At the village level, the list of all agricultural producers, including household producers, were obtained from the local administrations; agricultural producers were numbered, and then from this numbered list, respondents were randomly selected. Due to civil unrest during most of 2010 in southern Kyrgyzstan, it was impossible to include the three provinces in the south of Kyrgyzstan in the sampling. Similarly, Gorno-Badahshan autonomous province of Tajikistan was also excluded from sampling due its trivial share in agricultural production and population, as well as extremely high surveying costs due to its location in high altitude areas with difficult access (Fig. 2). In summary, in spite of these geographical gaps, the selected samples are well representative of the key areas in the region in terms of their share in the overall agricultural production, population, and different income levels.

\subsection{Methods}

As an initial step, an exploratory analysis of the survey datasets is conducted with the purpose of highlighting the major characteristics of the surveyed households. Then, two-stage regression is run to identify the impact of adoption of climate smart technologies on net farming profits. The purpose of the two-stage procedure is to address the endogeneity between the farming incomes and the adoption of CSATs. In the first stage, the probit model is used to regress the variable representing the adoption of climate smart agricultural practices on a number of explanatory variables including household, farm, climatic and institutional characteristics, also including the instrumental variable: access to extension services. The motivation for 


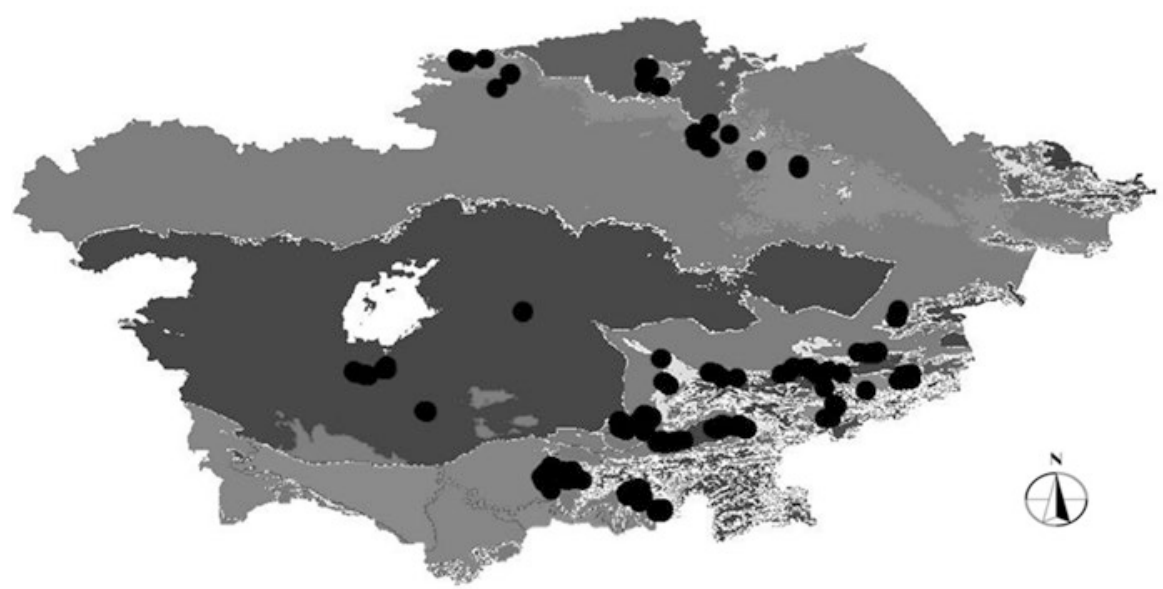

Fig. 2 Location of surveyed households across agro-ecological zones in Central Asia

using access to extension as instrument is because it affects farming incomes through adoption of CSATs only and households' access to extension is not affected by farming incomes. Extension is usually provided by the governments or by nonprofit/donor funded organizations in the region. In the second stage, net household farming profits are regressed using ordinary least squares (OLS) on the same explanatory variables as above (excluding the instrument) and the fitted values of adoption of climate smart technologies from the first stage.

However, to identify the distribution impacts on different categories of households, separate regressions are run for two categories of households. The first group with per capita daily food expenses less than the median for the whole sample $(0.83$ USD) - named as the "poor", and the group with per capita daily food expenses more than the medium, named as the "non-poor". The econometric model specifications for the first and second stages are given below.

\subsubsection{The First Stage}

$$
A=\alpha H+\beta C+\phi F+\delta I+\mu G+\epsilon
$$

where,

$\mathrm{A}=$ adoption of CSATs (0-no, 1-yes)

$\mathrm{H}=\mathrm{a}$ vector of household characteristics

$\mathrm{C}=\mathrm{a}$ vector of climate variables (temperature and precipitation, etc)

$\mathrm{F}=\mathrm{a}$ vector of farm characteristics, such as farm size and livestock value.

$\mathrm{I}=$ a vector of institutional variables (market access, land tenure, etc)

$\mathrm{G}=$ the instrumental variable: access to extension services

$\epsilon=$ error term 


\subsubsection{The Second Stage}

$$
\pi=\alpha H+\beta C+\phi F+\delta I+\mu f v A+e
$$

where,

$\pi=$ net farm profits

$\mathrm{H}=\mathrm{a}$ vector of household characteristics

$\mathrm{C}=\mathrm{a}$ vector of climate variables (temperature and precipitation, etc)

$\mathrm{F}=\mathrm{a}$ vector of farm characteristics, such as farm size and livestock value.

$\mathrm{I}=\mathrm{a}$ vector of institutional variables (market access, land tenure, etc)

$f v A=$ fitted values of adoption of climate smart technologies from the first stage

$\mathrm{e}=$ error term

\subsection{Variable Selection}

Literature on the adaptation to climate change in agriculture has strong linkages to the previous research on adoption of new technologies by agricultural producers, including under risky decision making contexts (Zilberman et al. 2012). Based on the previous lines of research and earlier work on agricultural adaptation to climate change per se, it is hypothesized that there are a number of variables which influence the adoption of CSATs. These variables are grouped into four major categories, following Gbetibouo (2009): (i) household characteristics, corresponding to human dimension of the five "capitals", (ii) farm characteristics (physical capital), (iii) climate-related variables (natural capital), and (iv) institutional variables.

\subsection{Household Characteristics}

Family size, age, education and gender of the household head are standard variables used in most adaptation and agricultural technology adoption studies, though there is no firm theoretical consensus on the direction of their impact on adaptation/adoption. In most cases, this is a matter of empirical analysis and can differ from one context to another. Income of the household may have an effect on adaptation as richer households have more resources and relatively greater adaptive capacities making them more likely to adapt. To capture the income status of the households the value of total household assets are used. 


\subsection{Farm Characteristics}

Total farm size is expected to have a positive effect on technology adoption as economies of scale could allow undertaking adaptation measures with scalesensitive costs. Many rural households in Central Asia keep livestock as one of the key saving and investment strategies, hence the value of the livestock owned (different from income status) by the household can be a good indicator of the level of adaptive capacity.

\subsection{Climatic Characteristics}

Higher frequency of climatic shocks can provide with more incentives for adaptation. Significance of these variables would also corroborate the intuition that unless Governments encourage farmers for ex ante adaptation most of adaptation to climate change could be ex post. It is believed that many impacts of climate change would be felt along the agro-ecological zones, hence the estimation includes indicators for agro-ecological zones. Higher long-term climate variability (30 years, 1980-2010) in terms of more variable temperature and precipitation could necessitate a more adaptive behavior. Finally, the estimation also takes into account long-term average precipitation and temperature (30 years, 1980-2010). The climate variables have been compiled for about 400 weather stations across Central Asia. The data come from national meteorological agencies, Williams and Konovalov (2008), NASA's Global Summary of the Day, and other sources. Climate variables from individual weather stations were spatially projected to the digital map of Central Asia using spatial interpolation technique of inverse weighted distance. Following this, corresponding weather variables were extracted for each household using the GPS location of the household.

\subsection{Institutional Characteristics}

Land tenure is a potentially important factor influencing farmers' decisions, including those on adapting to climate change (Quan and Dyer 2008). Adaptation to climate change may lead to increased production costs and/or necessitate long-term farm investments. Quan and Dyer (2008) note that secure land tenure arrangements are needed for better climate change adaptation. Farmers in Central Asia may operate several parcels with different tenure arrangements ranging from privately owned to those leased from the State. To measure this in one variable, taking into account different levels of incentives for long-term investments inherent to different land tenure arrangements, the share of privately owned land area in the total farm size is used in the model, even though, admittedly, this variable may not perfectly capture 
the tenure security. Higher market access would normally lead to more adaptation. The country dummies are included to implicitly account for other country-specific characteristics that are not included in the models explicitly. The intensity of nighttime lighting (DMSP-OLS Nighttime Lights Time Series, NOAA's National Geophysical Data Center, using the data collected by US Air Force Weather Agency) is used as a proxy for availability of electricity. More lighting could indicate at economic dynamism of the region and availability of non-farm job opportunities.

\section{Results and Discussion}

The survey responses show that about $62 \%$ of the respondents adopted at least one CSAT. The adoption rates among the poorer half of the households are lower than among richer half of the households (Fig. 3).

Many households in the surveyed sample, especially poorer households, report to be constrained in their technology adoption by lack of credit, inputs, water and information (Fig. 4). Major constraints to adaptation that are faced specifically by poorest one third of agricultural households are found to be lack of access to credit and inputs.

Table 1 presents the mean values for some major variables used in the analysis segregated by country. Country-wise in the region, the adoption of climate smart technologies is higher in Uzbekistan and Tajikistan, and the lower in Kyrgyzstan. Agricultural households in Uzbekistan and Tajikistan also report to have much higher access to extension services. There are no major differences among the households in the countries of the region in terms of their demographic characteristics. Farm sizes are the largest in Kazakhstan and lowest in Tajikistan and Kyrgyzstan. In terms of total assets, the households in Kazakhstan are much richer than those in other countries of the region. In general, Table 1 shows that despite considerable similarities across the countries of the region, there are also substantial structural and institutional differences, which need to be taken into account while devising country-specific polices for promoting resilience to climate change. In this paper, the focus is on common patterns across the region and discuss about development policies that could be beneficial across different settings in the region.

Specifically, Table 2 presents the findings on the major determinants of the adoption of CSATs (CSATs) in the region (the first stage of the estimation) and Table 3 presents the estimation of potential impacts of adoption of CSATs among households of two categories (the poorer half of the sample and the richer half) (2nd stage).

The results in the first stage indicate that the selected instrument, extension services, positively influences the adoption of climate smart technologies with statistical significance at 5\%. The F-statistic of the excluded instrument is equal to 19.43, which points also at the statistical validity of the instrument. Access to extension would increase the knowledge and information of the households about CSATs and the ways to apply them in their farms, thus allowing for higher adoption of CSATs 


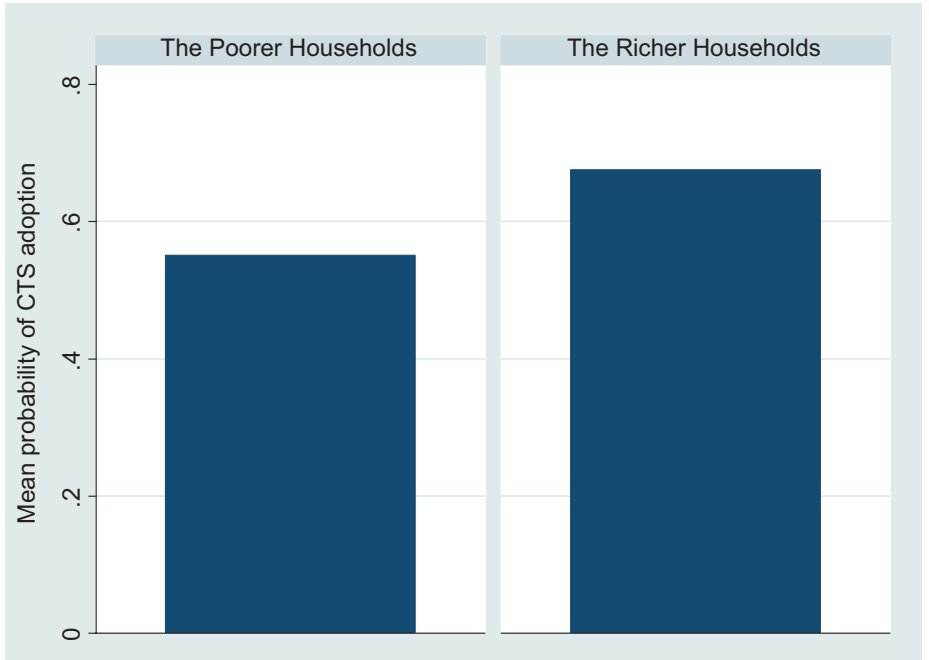

Fig. 3 CSAT adoption by households according to per capita food consumption (below and above medium food expenses per capita). $0=$ no, $1=$ yes

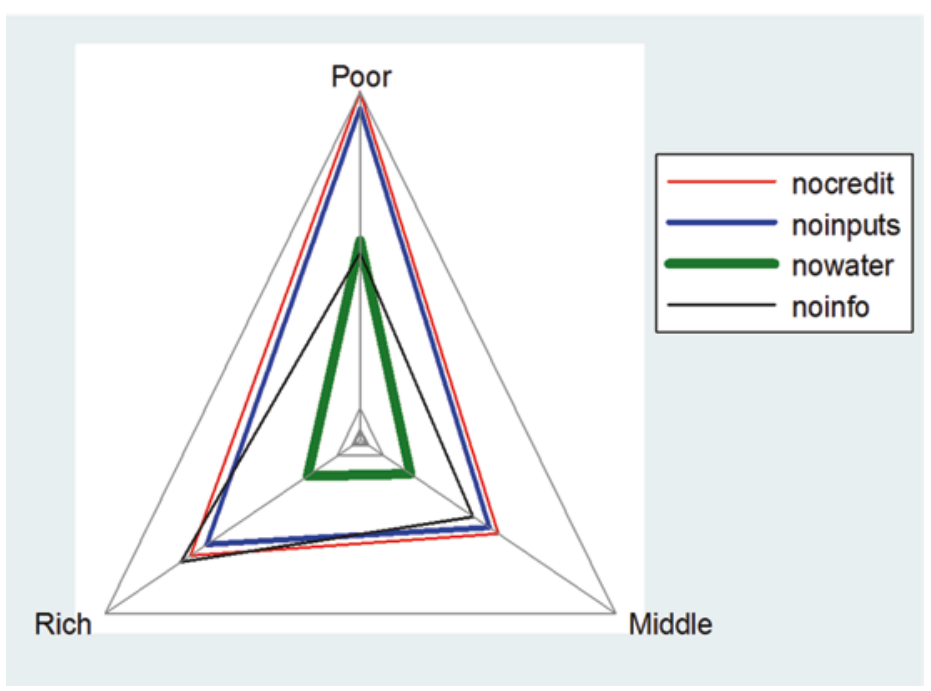

Fig. 4 Constraints to CSAT adoption by household's economic status (Terciles food expenses per capita) 
Table 1 Mean values of key household, institutional, and environmental characteristics

\begin{tabular}{l|l|l|l|l}
\hline Variables & Kazakhstan & Kyrgyzstan & Tajikistan & Uzbekistan \\
\hline $\begin{array}{l}\text { Number of climate smart } \\
\text { technologies used }\end{array}$ & 2.8 & 0.2 & 4.4 & 4.9 \\
\hline Household size & 6 & 6 & 8 & 6 \\
\hline Age of household head in years & 51 & 50 & 52 & 47 \\
\hline Length of growing periods in months & 97 & 102 & 131 & 92 \\
\hline Annual precipitation in mm & 402 & 448 & 486 & 289 \\
\hline Annual temperature in degree Celsius & 7.0 & 5.7 & 14.4 & 14.4 \\
\hline $\begin{array}{l}\text { The number of weather shocks during } \\
\text { the last 5 years }\end{array}$ & 2.7 & 0.4 & 1.1 & 1.4 \\
\hline Land tenure (0-not private, 1-private) & 0.63 & 0.90 & 0.73 & 0.60 \\
\hline Farm size in hectares & 194 & 5 & 4 & 28 \\
\hline Access to extension (binary) & 0.1 & 0.2 & 0.7 & 0.7 \\
\hline Value of livestock (in USD) & 5255 & 8998 & 869 & 6796 \\
\hline Distance to markets (in minutes) & 133 & 150 & 59 & 75 \\
\hline Value of total assets (in USD) & 83,123 & 20,727 & 7407 & 34,939 \\
\hline
\end{tabular}

Source: Mirzabaev (2013)

(Deressa et al. 2009). However, as we have seen in Table 1 and Fig. 4, access to extension services and to information remains inadequate in many parts of the region. Hence, there is a need for public polices and development interventions facilitating greater access to extension among agricultural producers. Other major factors found to be positively affecting the adoption of climate smart technologies are better access to markets and commercialization of the households farming activities (vs. subsistence production), length of growing days and frequency of weather shocks.

Both access to markets and higher commercialization of the produce allow households to increase the profitability of their sales, thus incentivizing and enabling them to make investments into CSATs (von Braun and Kennedy 1994). In the face of higher frequency of weather shocks households might adopt CSATs precisely for increasing the resilience of their production activities against these shocks. The factors which are negatively associated with the adoption are night time lighting intensity, share of the land privately owned. Moreover, the likelihood of adoption of climate smart technologies is lower in more humid areas as compared to arid agroecological zones. The night time lighting intensity is used here as a proxy for availability of non-farm jobs. Better access to non-farm jobs could increase the opportunity costs of farm labor, thus making it costlier to adopt labor-intensive CSATs. Whereas the negative impact of the share of land held under private property on adoption is surprising, it is true that this variable used here is an imperfect proxy for land tenure security.

The second stage of the regression shows that the adoption of CSATs has a positive impact on the net farming profits of both poorer and richer households, with higher levels of positive impacts on the net profits of the richer households. The share of land under private property is another major factor positively affecting farm 
Table 2 The 1st stage results. Determinants of CSAT adoption

\begin{tabular}{|c|c|c|}
\hline Variables & Coef. & Conf. interval \\
\hline Access to extension (binary) & $0.527 * * *$ & $(0.294$ to 0.761$)$ \\
\hline Age of household head & $0.0485^{*}$ & $(-0.00334$ to 0.100$)$ \\
\hline Age of household head, squared & -0.000398 & $(-0.000892$ to $9.55 \mathrm{e}-05)$ \\
\hline Education of $\mathrm{HH}$ head & -0.0324 & $(-0.368$ to 0.303$)$ \\
\hline Education of $\mathrm{HH}$ head, squared & 0.0134 & $(-0.0558$ to 0.0826$)$ \\
\hline Gender of HH head (0-female, 1-male) & -0.0545 & $(-0.299$ to 0.190$)$ \\
\hline Family size & 0.000330 & $(-0.0289$ to 0.0295$)$ \\
\hline Distance to markets $(\log )$ & $-0.134 * *$ & $(-0.249$ to -0.0191$)$ \\
\hline Night-time lighting intensity & $-0.0146 * *$ & $(-0.0267$ to -0.00241$)$ \\
\hline Total household assets & $3.00 \mathrm{e}-06$ & $(-2.40 \mathrm{e}-06$ to $8.41 \mathrm{e}-06)$ \\
\hline Livestock value & $-3.44 \mathrm{e}-06$ & $(-1.12 \mathrm{e}-05$ to $4.35 \mathrm{e}-06)$ \\
\hline Farm size (ha) & 0.00183 & $(-0.00122$ to 0.00488$)$ \\
\hline Aridity level & 0.254 & $(-1.353$ to 1.861$)$ \\
\hline Length of growing days & $0.0160 * * *$ & (0.00779 to 0.0242$)$ \\
\hline Share of land privately owned & $-0.443 * * *$ & $(-0.680$ to -0.207$)$ \\
\hline \multicolumn{3}{|l|}{ Agro-ecological zone (base: arid) } \\
\hline Semiarid & $-2.245^{* * *}$ & $(-3.089$ to -1.400$)$ \\
\hline Sub-humid & $-2.702 * * *$ & $(-3.697$ to -1.707$)$ \\
\hline Humid & $-1.765 * *$ & $(-3.186$ to -0.345$)$ \\
\hline Subsistence farmer (binary) & $0.499 *$ & $(-0.00377$ to 1.001$)$ \\
\hline Mean annual temperature & 0.0314 & $(-0.00965$ to 0.0725$)$ \\
\hline Annual precipitation & $0.00142 * *$ & (0.000262 to 0.00258$)$ \\
\hline Variance of precipitation & $-0.00787 * * *$ & $(-0.0111$ to -0.00466$)$ \\
\hline Variance of temperature & 0.0406 & $(-0.119$ to 0.200$)$ \\
\hline $\begin{array}{l}\text { Number of weather shocks during the last } \\
5 \text { years }\end{array}$ & $0.0577 * *$ & $(0.00453$ to 0.111$)$ \\
\hline \multicolumn{3}{|l|}{ Country dummies (base: Kazakhstan) } \\
\hline Kyrgyzstan & $-1.575^{* * *}$ & $(-2.048$ to -1.103$)$ \\
\hline Tajikistan & $-0.982 * * *$ & $(-1.455$ to -0.508$)$ \\
\hline Uzbekistan & $0.955^{* * * *}$ & $(0.516$ to 1.394$)$ \\
\hline Constant & 0.447 & $(-1.306$ to 2.201$)$ \\
\hline R-squared & 0.43 & \\
\hline F-Statistic of the excluded instrument & 19.43 & \\
\hline
\end{tabular}

$* * * \mathrm{p}<0.01, * * \mathrm{p}<0.05, * \mathrm{p}<0.1$

profitability for both poorer and richer households. On the other hand, there are several variables with statistically significant effects only under one category of households. There are no variables with statistically significant opposite signs under the two categories of households. Better access to markets, higher livestock assets, and previous experiences with weather shocks seem to be positively related to higher on-farm profitability, especially among the poorer agricultural households. 
Table 3 The 2nd stage results. Potential impacts of CSAT adoption

\begin{tabular}{|c|c|c|}
\hline & $\begin{array}{l}\text { Stage } 2 \text {, Poorer households, } \\
\text { net farming profits ( } \log )\end{array}$ & $\begin{array}{l}\text { Stage } 2 \text {, Richer households, } \\
\text { net farming profits (log) }\end{array}$ \\
\hline Variables & Coef. & Coef. \\
\hline CSAT adoption, fitted values & $0.205^{*}$ & $0.531 * * *$ \\
\hline Age of household head & -0.000785 & -0.00924 \\
\hline $\begin{array}{l}\text { Age of household head, } \\
\text { squared }\end{array}$ & $9.13 \mathrm{E}-06$ & $8.45 \mathrm{E}-05$ \\
\hline Education of HH head & 0.0202 & 0.0138 \\
\hline Education of $\mathrm{HH}$ head, squared & -0.00869 & -0.000772 \\
\hline $\begin{array}{l}\text { Gender of HH head ( } 0 \text {-female, } \\
1 \text {-male) }\end{array}$ & 0.0391 & 0.0477 \\
\hline Family size & -0.000273 & 0.00958 \\
\hline Distance to markets $(\log )$ & $-0.0293 * *$ & 0.0161 \\
\hline Night-time lighting intensity & 0.000417 & $0.00566 * * *$ \\
\hline Total household assets & $4.41 \mathrm{E}-08$ & $2.72 \mathrm{E}-07$ \\
\hline Livestock value & $4.01 \mathrm{e}-06 * * *$ & $1.76 \mathrm{E}-07$ \\
\hline Farm size (ha) & $-0.000220^{*}$ & -0.000205 \\
\hline Aridity level & -0.245 & 0.172 \\
\hline Length of growing days & $-0.00204 *$ & $-0.00264 *$ \\
\hline Share of land privately owned & $0.193 * * *$ & $0.201 * * *$ \\
\hline \multicolumn{3}{|l|}{$\begin{array}{l}\text { Agro-ecological zone } \\
\text { (base-arid) }\end{array}$} \\
\hline Semiarid & $0.230 * * *$ & 0.115 \\
\hline Sub-humid & $0.393 * * *$ & 0.196 \\
\hline Humid & $0.459 * * *$ & 0.0538 \\
\hline Subsistence farmer (binary) & 0.0351 & -0.0856 \\
\hline Mean annual temperature & $0.0132 * * *$ & 0.00905 \\
\hline Annual precipitation & -0.00014 & $-9.04 \mathrm{E}-05$ \\
\hline Variance of precipitation & 0.000254 & $0.00138 * * *$ \\
\hline Variance of temperature & $-0.0804 * * *$ & $-0.0545^{* *}$ \\
\hline $\begin{array}{l}\text { The number of weather shocks } \\
\text { during the last years }\end{array}$ & $0.0122 *$ & -0.00138 \\
\hline \multicolumn{3}{|l|}{$\begin{array}{l}\text { Country dummies } \\
\text { (base-Kazakhstan) }\end{array}$} \\
\hline Kyrgyzstan & $0.239 * *$ & $0.348 * * *$ \\
\hline Tajikistan & 0.125 & 0.0102 \\
\hline Uzbekistan & 0.0219 & -0.00421 \\
\hline Constant & $8.975 * * *$ & $8.559 * * *$ \\
\hline R-squared & 0.244 & 0.186 \\
\hline Number of observations & 760 & 758 \\
\hline
\end{tabular}

$* * * \mathrm{p}<0.01, * * \mathrm{p}<0.05, * \mathrm{p}<0.1$ 


\section{Discussion and Policy Implications}

The results presented in this paper indicate that the adoption of CSATs increases the on-farm profitability. In their extensive review of climate smart and sustainable land management technologies (SLM) in the region, Pender et al. (2009) also find that cost-benefit ratios of many SLM technologies such as zero tillage, mulching, improved irrigation techniques, raised bed planting, etc. are positive in the region, often substantially so, thus corroborating the findings of this paper. However, the adoption rates of these technologies remain relatively low. These low adoption rates are often due to various barriers to adoption, as discussed above, such as lack of access to credit, to extension services and to input and output markets. Financial institutions can often be unwilling to extend credit to small-scale farming households with unknown risk profile and lack of collateral to guarantee the credit. In many instance, these farming households only lease their land from the State without the legal entitlement to use their land as collateral for obtaining credit. Government policies could target expanding farmers' legal rights in using their land leased from the State as collateral for obtaining credit. An alternative option would be government-financed soft loan programs to farmers targeting the adoption of new resource-efficient and climate smart technologies. The large scale adoption of conservation tillage practices in Kazakhstan on several millions of hectares was partially found to be facilitated by government subsidies promoting this technology (Kienzler et al. 2012). However, limited public funds may serve as barriers for other such programs at a larger scale, especially in the poorer parts of the region. Furthermore, the overall impact of such soft loan or subsidy programs on poverty reduction may also be reduced by asymmetric bargaining powers and access to credit funds between richer farmers and poorer farmers.

Other more promising areas for catalyzing the adoption of CSATs include providing better access to markets, including through better infrastructure, improving the investment climate for post-harvest processing and moving towards higher liberalization of input and output markets. In some countries of the region, input and output markets, as well as acreage decisions, especially for cotton and wheat crops, are still administratively managed by governments. Although abrupt removal of these regulation could be counter-productive in the short-term, gradual liberalization of the agricultural sector is likely to improve the agricultural profitability and reduce resource misallocations.

\section{Conclusions}

Central Asia is expected to experience a significant climate change in the coming decades, even though there are high uncertainties about the exact magnitudes of these changes. Importantly, previous studies point at important distributional effects of climate change on different categories of rural agricultural households, with 
more negative impacts on the poor. Given the uncertainties related with climate change, there is a need for such CSATs that would strengthen the resilience of agricultural production against a variety of climatic shocks, at the same time allowing for agricultural productivity growth and rural poverty reduction. This study finds a positive impact of the adoption of CSATs on agricultural revenues, both for poorer and richer households. Despite this potential, the adoption rates of CSATs remain relatively low in the region. The findings show that policy actions targeted towards improving access to markets and agricultural extension services, and higher commercialization of household agricultural production can serve as catalysts for the adoption of CSATs by rural households.

Although there are numerous analyses of the costs and benefits of adoption of CSATs at a farm level, larger scale effects of these adoptions, and social rates of returns from adopting these technologies need yet to be studied in the region. More information on the macroeconomic and social rates of returns from investing into CSATs as well as the extent of transaction costs for the implementation of CSAT programs and initiatives could provide with the necessary evidence base for better informed policies on the promotion of CSATs in Central Asia.

Acknowledgments I would like to thank Julia Anna Matz and the anonymous reviewer for their insightful and very helpful comments and suggestions. The data used in this study was collected by International Center for Agricultural Research in the Dry Areas (ICARDA) under a project funded by the Asian Development Bank (ADB).

\section{References}

Bobojonov. I, Sommer, R., Nkonya, E., Kato, E. and Aw-Hassan, A., (2012). Assessment of climate change impact on Central Asian agriculture: Bio-economic farm modeling approach. ICARDA Research report (unpublished). Syria

Branca, G. N. McCarthy, L. Lipper and M.C. Jolejole (2011): Climate Smart Agriculture: A Synthesis of Empirical Evidence of Food Security and Mitigation Benefits for Improved Cropland Management. Mitigation of Climate Change in Agriculture Series 3. Rome, Italy: Food and Agriculture Organization of the United Nations (FAO).

Chambers, R., Conway, G., (1992). Sustainable rural livelihoods : practical concepts for the 21st century. Brighton, England: Institute of Development Studies.

Deressa, T. T., Hassan, R. M., Ringler, C., Alemu, T., \& Yesuf, M. (2009). Determinants of farmers' choice of adaptation methods to climate change in the Nile Basin of Ethiopia. Global environmental change, 19(2), 248-255.

de Pauw, E., 2012. Downscaling Basic Climatic Variables for Central Asia. Adapta-tion to Climate Change in Central Asia and People's Republic of China. ICARDA, Aleppo.

Gbetibouo, G.A., (2009). Understanding Farmers' Perceptions and Adaptations to Climate Change and Variability. Discussion Paper 00849. International Food and Policy Research Institute.

Gupta, R., K. Kienzler, C. Martius, A. Mirzabaev, T. Oweis, E. de Pauw, M. Qadir, K. Shideed, R. Sommer, R. Thomas, K. Sayre, C. Carli, A. Saparov, M. Bekenov, S. Sanginov, M. Nepesov, and R. Ikramov (2009) Research Prospectus: A Vision for Sustainable Land Management Research in Central Asia. ICARDA Central Asia and Caucasus Program. Sustainable Agriculture in Central Asia and the Caucasus Series No.1. CGIAR-PFU, Tashkent, Uzbekistan. 
Kienzler, K. M., Lamers, J. P. A., McDonald, A., Mirzabaev, A., Ibragimov, N., Egamberdiev, O., ... \& Akramkhanov, A. (2012). Conservation agriculture in Central Asia-What do we know and where do we go from here?. Field Crops Research, 132, 95-105.

Kimmelshue, J. E., Gilliam, J. W., \& Volk, R. J. (1995). Water management effects on mineralization of soil organic matter and corn residue. Soil Science Society of America Journal, 59(4), $1156-1162$.

Lipper, L., P. Thornton, B.M. Campbell, T. Baedeker, A. Braimoh, M. Bwalya, P. Caron, A. Cattaneo, D. Garrity, K. Henry, R. Hottle, L. Jackson, A. Jarvis, F. Kossam, W. Mann, N. McCarthy, Alexandre Meybeck, H. Neufeldt, T. Remington, P.T. Sen, Reuben Sessa, R. Shula, A. Tibu and E. Torquebiau (2014): Climate-smart agriculture for food security. In: Nature Climate Change 2014(4), pp. 1068-1072. doi:10.1038/nclimate2437

McCarthy, N. and J. Brubaker (2014): Climate-Smart Agriculture and Resource Tenure in SubSaharan Africa: A Conceptual Framework. Rome, FAO.

Meinzen-Dick, R., Q. Bernier and E. Haglund (2012): The six "ins" of climate-smart agriculture: Inclusive institutions for information, innovation, investment, and insurance. CAPRi Working Paper No. 114. Washington, D.C.: International Food Policy Research Institute. http://dx.doi. org/10.2499/CAPRiWP114

Mendelsohn, R., (2000). Efficient adaptation to climate change. Climatic Change, Vol. 45, 583-600

Mertz, O., Mbow, Ch., Reenberg, A. and Diouf, A., (2009). Farmers' Perception of Climate Change and Agricultural Adaptation Strategies in Rural Sahel, Environmental Management, Vol. 43, 804-816

Mirzabaev, A.. 2013. Climate Volatility and Change in Central Asia: Economic Impacts and Adaptation. Doctoral mthesis at Agricultural Faculty, University of Bonn. urn:nbn:de:hbz:5n-3238

Nelson, G., Rosegrant, M., Palazzo, A., Gray, I., Ingersoll, C., Robertson, R., Tokgoz, S., Zhu, T., Sulser, T., Ringler, C., Msangi, S., and You, L., (2010). Food Security, Farming and Climate Change to 2050: Scenarios, Results, Policy Options', IFPRI Research Monograph, Washington, DC: IFPRI.

Nhemachena, Ch. and Hassan, R. (2007). Micro-Level Analysis of Farmers' Adaptation to Climate Change in Southern Africa. IFPRI Discussion Paper 00714

IPCC, (2007). Climate Change 2007: The Scientific Basis. Contribution of Working Group I to the Fourth Assessment Report of the Intergovernmental Panel on Climate Change, edited by S. Solomon et al., Cambridge Univ. Press, New York

O'Connor, R., Bord, R., and Fisher, A., (1999). Risk Perceptions, General Environmental Beliefs, and Willingness to Address Climate Change. Risk Analysis, Vol.19, No. 3, 461-471

Osberghaus, D., Finkel, E., and Pohl, M., (2010). Individual adaptation to climate change: The role of information and perceived risk. Discussion Paper No. 10-061. Center for European Economic Research.

Pender, J., Mirzabaev, A., \& Kato, E. (2009). Economic Analysis of Sustainable Land Management Options in Central Asia. Final report for the ADB. IFPRI/ICARDA, 168.

Quan, Julian and Dyer, Nat (2008) Climate change and land tenure: the implications of climate change for land tenure and land policy. Working Paper. Food and Agriculture Organization of The United Nations, Rome.

Seo, S.N., (2011). An Analysis of Public Adaptation to Climate Change Using Agricultural Water Schemes in South America", Ecological Economics, Vol. 70, No. 4, 825-834

Sommer, R., Glazirina, M., Yuldashev, T., Otarov, A., Ibraeva, M., Martynova, L., ... \& De Pauw, E. (2013). Impact of climate change on wheat productivity in Central Asia. Agriculture, ecosystems \& environment, 178, 78-99.

Stulina G. (2008). Acting Today, Preparing for Tomorrow, Case study Central Asia. Addressing Water Scarcity and Drought in Central Asia Due to Climate Change. Presentation ICWC, available online at https://www.google.de/url?sa=t\&rct=j\&q=\&esrc=s\&source=web\&cd=13 \&ved=0ahUKEwiGjPXYpfLUAhVGDJoKHXZcAQM4ChAWCCswAg\&url=http\%3A\%2F \%2Fwww.wkhcca.my\%2Fdownload.php\%3Ffile\%3D318\&usg=AFQjCNGMXGu6tk_pv0_ WgEi7_MheeQLPFQ, access 05 July 2017. 
Tilman, D., P.B. Reich and J. Knops (2006): Biodiversity and ecosystem stability in a decade-long grassland experiment. In: Nature 2006(441), pp. 629-632. doi:10.1038/nature04742.

Tversky, A., Kahneman, D., (1986). Rational Choice and the Framing of Decisions. The Journal of Business, 59(4), S251-S278.

von Braun, J. V., \& Kennedy, E. (1994). Agricultural commercialization, economic development, and nutrition. Johns Hopkins University Press.

Wheeler, T., \& von Braun, J. (2013). Climate change impacts on global food security. Science, 341(6145), 508-513.

Williams, M. and Konovalov, V. (2008). Central Asia Temperature and Precipitation Data, 18792003. Boulder, Colorado: USA National Snow and Ice Data Center. Digital media.

Zilberman, D., Liu, X., Roland-Holst, D., \& Sunding, D. (2004). The economics of climate change in agriculture. Mitigation and Adaptation Strategies for Global Change, 9(4), 365-382.

Zilberman, D., Zhao, J., \& Heiman, A. (2012). Adoption versus adaptation, with emphasis on climate change. Annu. Rev. Resour. Econ., 4(1), 27-53.

Open Access This chapter is distributed under the terms of the Creative Commons AttributionNonCommercial-ShareAlike 3.0 IGO license (https://creativecommons.org/licenses/by-nc-sa/3.0/ igo/), which permits any noncommercial use, duplication, adaptation, distribution, and reproduction in any medium or format, as long as you give appropriate credit to the Food and Agriculture Organization of the United Nations (FAO), provide a link to the Creative Commons license and indicate if changes were made. If you remix, transform, or build upon this book or a part thereof, you must distribute your contributions under the same license as the original. Any dispute related to the use of the works of the FAO that cannot be settled amicably shall be submitted to arbitration pursuant to the UNCITRAL rules. The use of the FAO's name for any purpose other than for attribution, and the use of the FAO's logo, shall be subject to a separate written license agreement between the FAO and the user and is not authorized as part of this CC-IGO license. Note that the link provided above includes additional terms and conditions of the license.

The images or other third party material in this chapter are included in the chapter's Creative Commons license, unless indicated otherwise in a credit line to the material. If material is not included in the chapter's Creative Commons license and your intended use is not permitted by statutory regulation or exceeds the permitted use, you will need to obtain permission directly from the copyright holder. 